\title{
Integration Manager Technology in ERPApplication System (Case Study: PT. ARGO PANTES, TBK)
}

\author{
Verri Kuswanto ${ }^{1}$ Rudy Arijanto ${ }^{2}$, Andi Leo ${ }^{3}$, \\ ${ }^{1,3}$ Buddhi Dharma University, Information System, Banten, Indonesia \\ ${ }^{2}$ Buddhi Dharma University, Teknik Informatika, Banten, Indonesia
}

\begin{tabular}{l} 
SUBMISSION TRACK \\
\hline Recieved: Feb 11, 2020 \\
Final Revision: Feb 19, 2020 \\
Available Online: Feb 26, 2020
\end{tabular}

KEYWORD

Technology Integration Manager, ERP

(Enterprise Resource Planning) Application, Matrix TOWS.

CORRESPONDENCE

E-mail: verri.kuswanto@ubd.ac.id

\begin{abstract}
A B S T T R A C T
Many companies are already using ERP application systems but still do not utilize information technology as an interest in helping to achieve the goals of the company's vision. The process of inputting the ERP (Enterprise Resource Planning) application data that prioritizes data integration, the accuracy of the data from the master data to the daily transaction data is then recorded into a financial statement information for the related. From this research, the results achieved are the ERP application system in inputting data integration processes, master data and transaction data are able to validate the level of data accuracy with the help of the INTEGRATION MANAGER Technology which functions as the initial data matrix with ready-to-report data in an ERP application system, As for the TOWS Matrix Analysis external environment (threats and opportunities), and internal environment (weaknesses and strengths) in summarizing the conclusions reached are to help the accuracy of the data in the ERP application of PT. Argo Pantes, Tbk is more structured, more efficient, reduces input errors, input data is correct, accompanied by uptodate managerial decisions
\end{abstract}

\section{INTRODUCTION}

With the rapid development of the use of information technology in the implementation of ERP applications, with this there are still many companies that integrate information management systems in their organizations using many applications either by making themselves or by collaborating with application vendors, then each individual wants to increase effectiveness and efficiency in each work .
Many things are still unknown that applying information technology in operational work optimally, one of them is the integration manager technology, the process of data collection and also the process of integration in ERP applications becomes faster and more efficient, because this integration manager process is a technology where the system is able maintain validation - validation which if done by the User error can occur, so this process helps a lot in the efficiency of 
working time from the level of errors that occur. PT. Argo Pantes, Tbk. Is one of the industry companies that implement the Integration Manager implementation in ERP applications, this is supported by supporting from the Information Systems Management department (MIS) and the consultant (Vendor). The implementation of Integration Manager is still in the initial stages where the related Project Team is still doing a lot of business process analysis in order to achieve its level of efficiency, several systems from outside have implemented this integration manager concept for example: SAP software, Microsoft Dynamics GP, Axapta Software, INTEX Software and the other.

In the last few messages, the ERP software system implementation at PT. Argo Pantes, Tbk still has some technical matters related to business processes that still need to be found a solution so that the implementation of integration manager can run smoothly without much resistance from the relevant user. By implementing the Standard Operational Procedure (SOP) in practicing the way the integration manager works in an ERP system application.

For this reason, this paper is compiled based on the results of a review that is able to update information to be able to provide innovation and planning actions in the future so that the ERP application is able to have a good impact and improve business process work efficiently for PT. Argo Pantes, Tbk.

\section{LITERATURES REVIEW}

\subsection{ERP Application}

Wijaya, Santo ERP application is defined as a system that is implemented in a company / business organization, where the application aims at making decisions for the user, in this case the management level [1]. In an ERP application a lot of integration is connected from the start of master data, transactions, inquiry, until the presentation of financial statements. Enterprise Resource Planning (ERP) itself has an understanding that is a business management application that facilitates integrated business management, ERP integrates various information systems within the company. ERP is able to provide real-time information about the company's core business processes such as production, order processing, and inventory management. ERP monitors company resources such as money, raw materials, production capacity, and employees [2].

ERP focuses on automation of internal functions such as accounting and finance, purchasing and warehousing, logistics, production and maintenance, sales and distribution, and payroll and staffing. Then the front-office functions are also incorporated into ERP such as CRM (Customer Relationship Management) and SCM (Supplier Change Management) [3]. The application of internet portal technology in ERP allows companies to conduct various collaborations. Both collaboration between employees within the company and company collaboration that implements ERP with its Integration Manager. With such components, ERP can be a complete solution to answer the needs of integrated information systems for companies.

\subsection{Integration Manager}

Business Process Reengineering (BPR) is a change in an organization's business processes by following the Enterprise Systems business processes[4]. Changes in business process systems must be balanced with changes in ERP applications used in an organization, then the common way is to make changes in ERP applications that cause the master data component to be followed up. Integration Manager works using applications that are created with the aim of being a liaison between current users who use operational data must be changed to with 
automatic data integration[5]. And the user's ERP applications themselves. Therefore, it is key functions are becoming more effective, necessary to understand about Corporate efficient to focus on training in the use of Application Integration(EAI). [6]

Table 1. Overview of the strengths and weaknesses of Enterprise Application Integration (EAI) approaches

\begin{tabular}{|c|c|c|}
\hline Integration Approach & Strength & Weakness \\
\hline Data & Simple to implement & Does not invoke business \\
\hline \multirow{5}{*}{$\begin{array}{l}\text { Shares data between } \\
\text { multiple data sources }\end{array}$} & Inexpensive to implement & \multirow[t]{5}{*}{ logic } \\
\hline & Consistent data Minimum & \\
\hline & changes to the source or target & \\
\hline & applications Provides access to & \\
\hline & wide range of data & \\
\hline Object & Integrate business logic & Complex Difficult approach \\
\hline Integrates objects & Reusable & \\
\hline \multirow{2}{*}{\multicolumn{3}{|c|}{$\begin{array}{l}\text { distributed throughout the } \\
\text { enterprise }\end{array}$}} \\
\hline & & \\
\hline Process & Real time tracking and analysis & Complex to architect \\
\hline \multirow{3}{*}{$\begin{array}{l}\text { Business process modeling } \\
\text { and integration }\end{array}$} & of business process Dynamic & \multirow[t]{3}{*}{ Expensive to implement } \\
\hline & process optimization and & \\
\hline & adjustment Process evaluation & \\
\hline User Interface & Easy to implement Requires & Tightly coupled application \\
\hline \multirow{4}{*}{$\begin{array}{l}\text { Build new interface by re- } \\
\text { mapping old interface }\end{array}$} & \multirow{4}{*}{$\begin{array}{l}\text { minimum change to existing } \\
\text { application }\end{array}$} & Synchronous communication \\
\hline & & Difficult to maintain Cannot \\
\hline & & scale Doesn't take place at \\
\hline & & actual interconnection \\
\hline \multirow{7}{*}{$\begin{array}{l}\text { Application Interface } \\
\text { Exposes an interface for } \\
\text { sharing business } \\
\text { functionality }\end{array}$} & \multirow[t]{7}{*}{ Invokes application functionality } & interface Exposes an \\
\hline & & interface for sharing business \\
\hline & & functionality. Tightly \\
\hline & & coupled application \\
\hline & & Synchronous communication \\
\hline & & Require same API for both \\
\hline & & application \\
\hline
\end{tabular}




\subsection{TOWS Matrix}

The TOWS matrix is a method used in developing 4 types of strategy choices: SO, WO, ST and WT[7]. The key to the successful use of the TOWS matrix is combining key internal and external factors to form a strategy

1. SO strategy is a strategy that is made by using the company's internal strength to take advantage of external opportunities.

2. WO strategy is a strategy designed to correct internal deficiencies and use external opportunities. WO also shows the opportunities that exist in the environment that can be achieved by the company if it is successful in fixing internal weaknesses.

3. The ST Strategy is made to anticipate external threats by using internal strengths.

4. The WT strategy might occur especially if the company faces factors of weakness and threat that cannot be dealt with by using existing strengths and opportunities. the forms of WT strategy implementation are mergers, financial statements, restructuring, or liquidation.

Table 2. Matrix TOWS Analysis

\begin{tabular}{|c|c|c|c|}
\hline \multicolumn{4}{|c|}{ Internal Factor } \\
\hline \multirow{3}{*}{$\begin{array}{c}\text { External } \\
\text { Factor }\end{array}$} & & $\begin{array}{l}\text { Strengths } \\
\text { (S) }\end{array}$ & $\begin{array}{l}\text { Weaknesses } \\
(W)\end{array}$ \\
\hline & $\begin{array}{l}\text { Opportu } \\
\text { nities } \\
(O)\end{array}$ & $\begin{array}{l}\text { Strengths } \\
\text { Opportunitie } \\
\text { s(SO) }\end{array}$ & $\begin{array}{l}\text { Weaknesses } \\
\text { / } \\
\text { Opportuniti } \\
\text { es }(W O)\end{array}$ \\
\hline & $\begin{array}{l}\text { Threats } \\
(T)\end{array}$ & $\begin{array}{l}\text { Strenghts / } \\
\text { Threats }(S T)\end{array}$ & $\begin{array}{l}\text { Weaknesses } \\
/ \quad \text { Threats } \\
(W T)\end{array}$ \\
\hline
\end{tabular}

\section{FRAMEWORK}

Integration Manager is a development of a support system in an Enterprise Resource Planning application, where in a development there are several determinants in Integration Manager to do subtitles in the Enterprise Resource Planning Application[8]. Seeing the growing need for ERP applications with integration that is certain to have to run from the start of master data, transactions, and reports that are used routinely in decision making. Some factors are the weak integrity of the master data, transactions and reports due to errors in the input of the master data system, due to the weak controlling in the master data collection and daily transactions, for that with the support of sub systems such as the Integration Manager is able to identify problems that exist in the master data, transactions, and reports so that the output of Enterprise Resource Planning Applications can support business success in decision making [9]. Then the TOWS Matrix analysis is expected to be able to provide insight to users of Enterprise Resource Planning Applications to better understand data integration starting from the master data. Broadly speaking, the framework of thought set forth in the framework of thought)

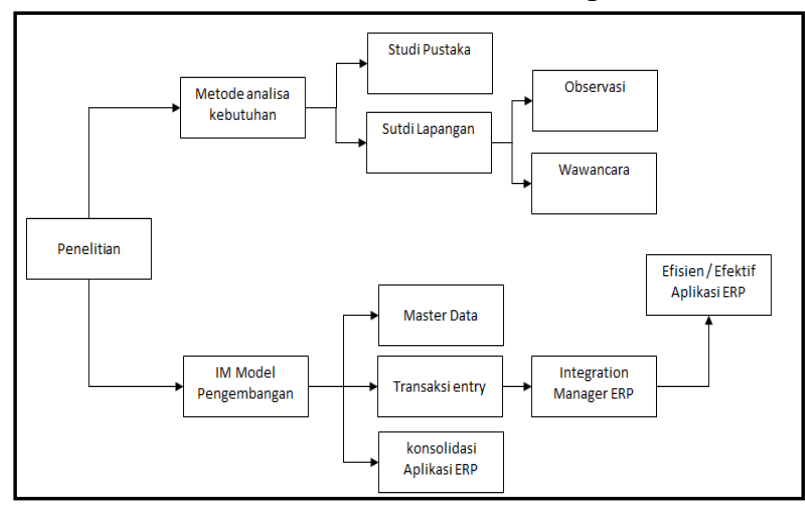

Figure 2. Framework Integration Manager

(Source: My Picture, 2019) 


\section{METHODS}

\subsection{ERP Application PT. Argo Pantes,} Tbk.

In implementing ERP applications, PT. Argo Pantes, Tbk is the use of operational applications, namely in terms of recording data from entry to completion until recorded in the financial statements [10], then the perception between the user and the IT team is very important in the use of this ERP application because with the foundation of equalization of perception that has gone well then in the process of using applications and ERP application development is more likely to run well even though there are still some developments that users still want with consideration of changes towards a better direction. Minor changes that often occur sometimes there is so that from the side of the IT team is still not too much overhauling the application that has been made. As for some ERP applications that are already running at PT. Argo Pantes, Tbk as follows:

1. ERP system sales application

2. ERP system purchase application

3. ERP system inventory application

4. ERP system application for production planning control (PPC)

5. ERP Application Production and Quality Control (QC) system

6. ERP Application Material Request Planning (MRP) system

7. ERP and Financial Controling (FiCo) system applications

\subsection{Current Activity Diagram Systems}

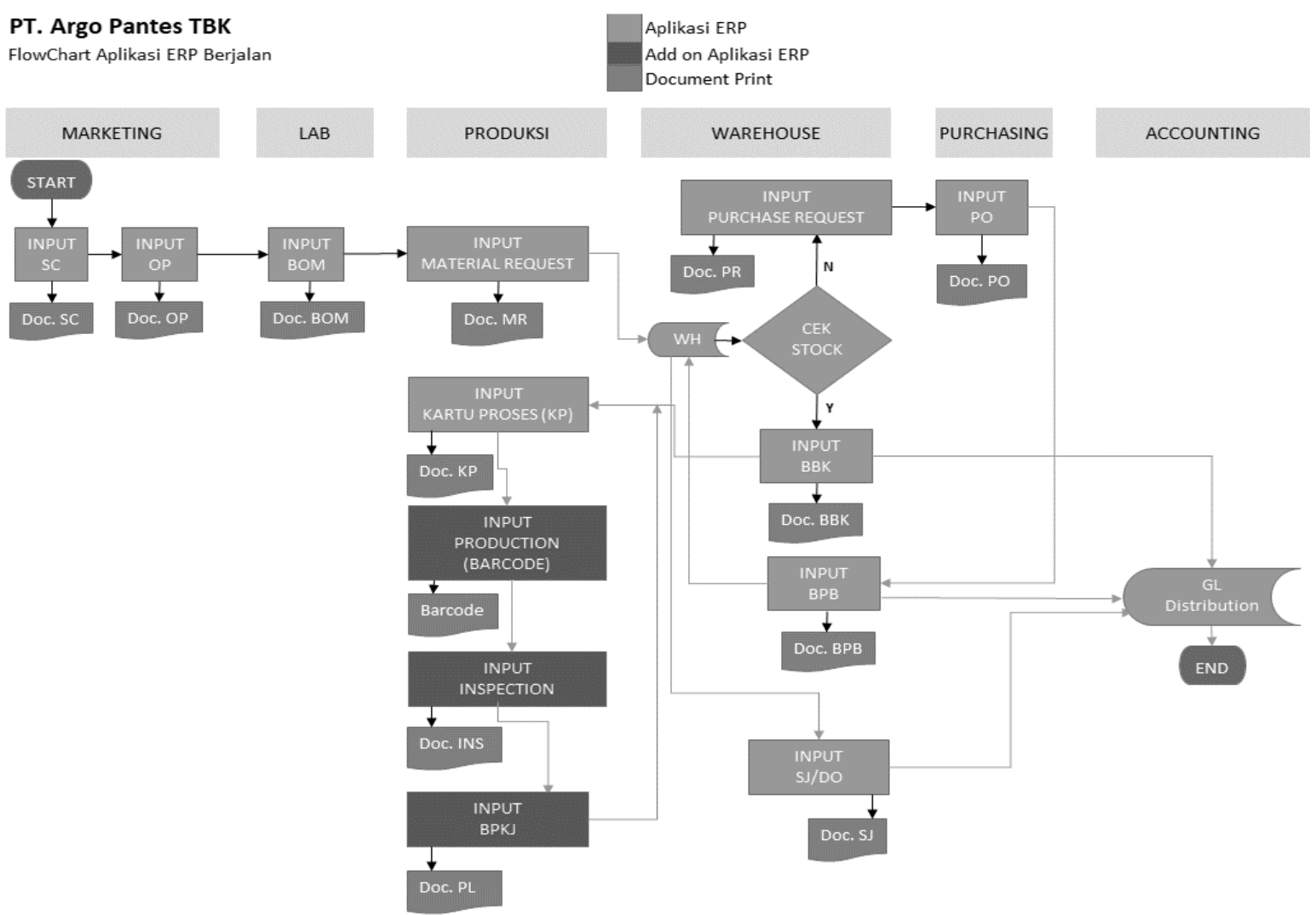

Figure 3. Current Activity diagram

Information:

1. Marketing makes production orders

2. Lab production makes bill of materials
3. Production makes request material

4. Warehouse check the stock of goods if available will be made a transfer item. 
5. Purchasing makes purchace orders of goods for several production orders

6. The warehouse receives goods for purchasing orders and a receipt material is made.

\subsection{ERP Application Enhancement}

After studying and analyzing the system that is running on the ERP application system at PT. Argo Pantes, Tbk, the discussion faced by the running ERP application is:

1. The process of inputting master data / master files in an ERP application that still looks one-on-one and can still experience a high level of errors so that sometimes the problem that arises is the input of master data / master files

2. The process of inputting routine transactions that should be done by uploading but still using re-inputting to produce more work, requires more accuracy and time.

3. The existence of other supporting ERP applications that are now in PT. Argo Pantes, Tbk still cannot be easily coordinated, it is still through the Management Information Systems (MIS) team that helps in consolidating data into the main Corporate ERP application.

\subsection{Analysis of information system enhancement needs}

Based on the results of interviews and observations, the information needed by the ERP application of PT. Argo Pantes, Tbk is as follows:

1.Integration Manager ERP application for master data

2.Integration Manager ERP application for routine transactions outside of ERP
3.Integration Manager ERP applications for the consolidation of other applications.

\section{RESULT}

\subsection{Integration Manager Configuration}

In configuring the integration manager, first it is necessary to install the integration manager application contained in the ERP application installer add-on in general, the integration version used in the case below is version V.11. The following is the installation display in the integration manager:

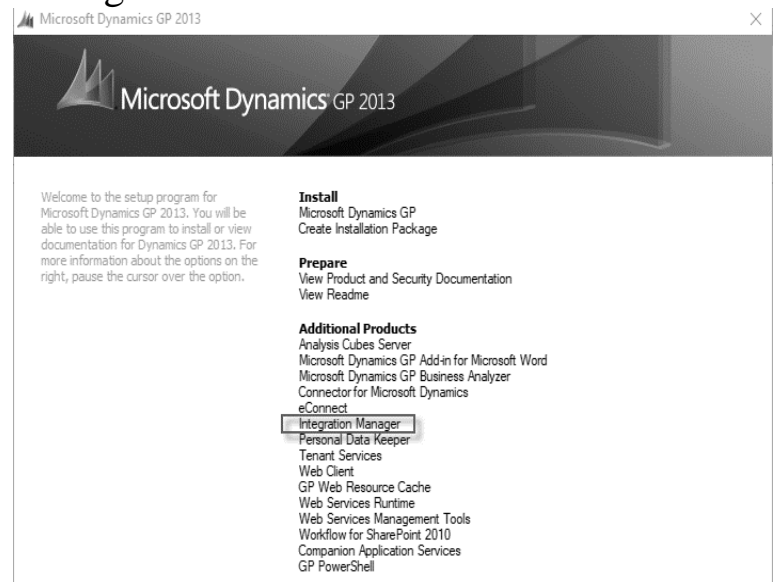

Figure 4. Configure Application Integration Manager

\subsection{Integration Manager Work}

Integration Manager that plays an important role in the increasing role of ERP application systems in the company PT. Argo Pantes, Tbk makes this AddOn application highly anticipated by Key Users / Users as ERP Application users in operational day-to-day operations. The concept of how Integration manager works can be translated into several stages:

\subsection{Mapping Template Integration Manager}

Integration Manager is a tool that becomes a medium between the needs of Key Users / Users in operating ERP applications at PT. Argo Pantes, Tbk. The following is the display mapping in integration manager: 



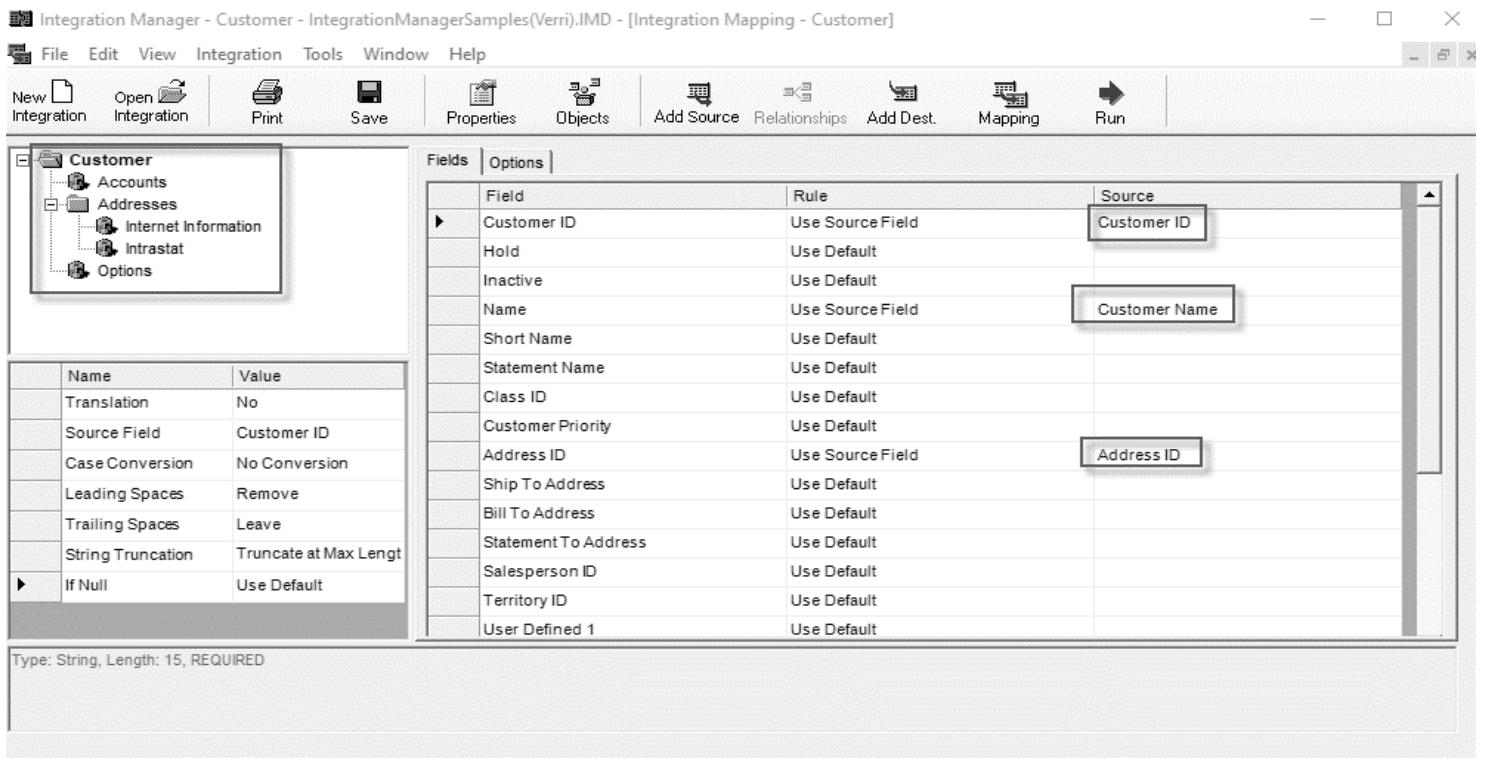

Figure 5. Integration Manager Template

\subsection{Upload with Integration Manager}

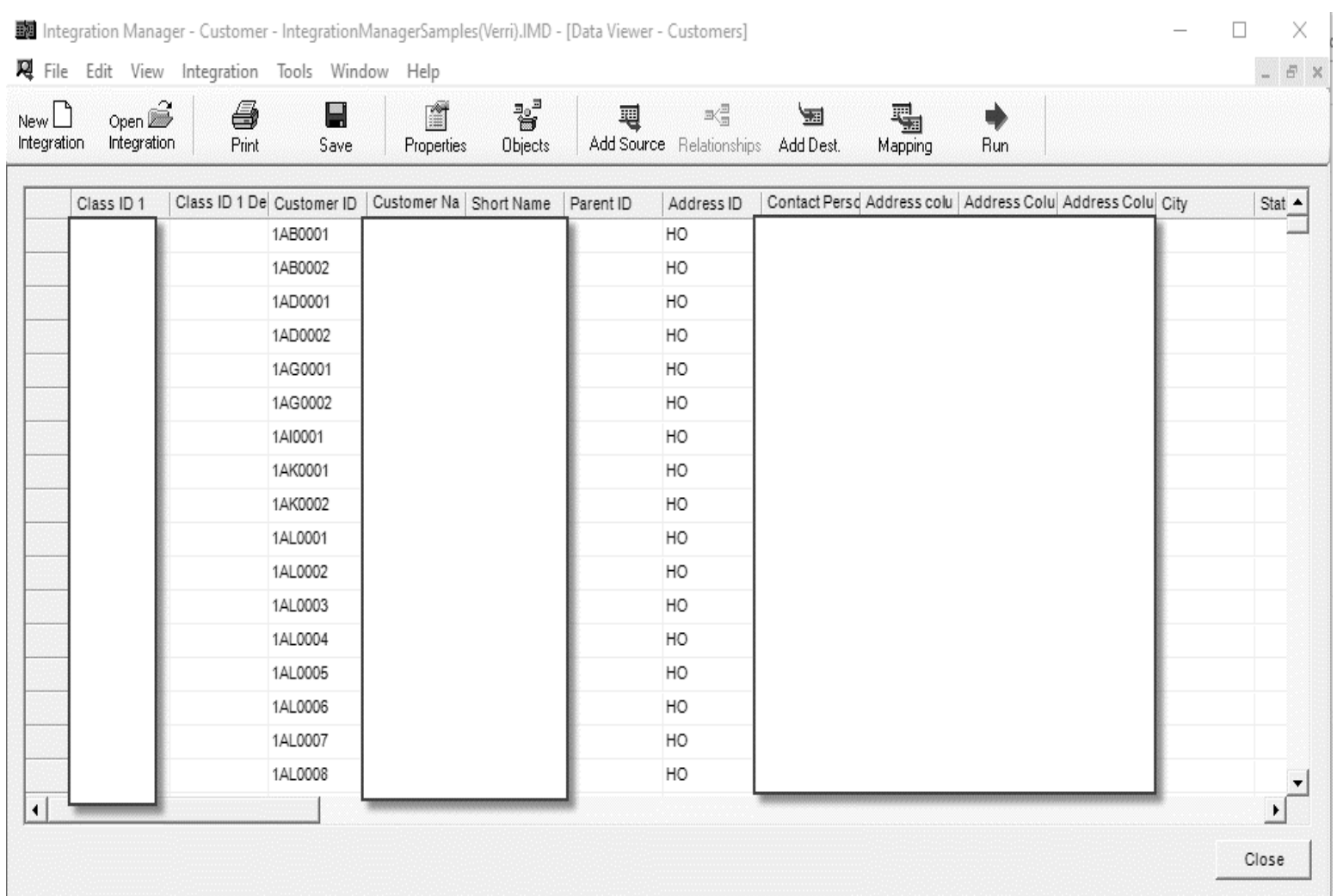

Figure 6. data migrate Integration Manager for ERP

Seen the picture above is the number of customer master files that are not yet in the ERP application, with the data above that the ERP application that is already running can also be transferred from the integration manager application so that the usual error level can be monitored by an application system that has been well implemented at PT. Argo Pantes, Tbk. After the data is perfectly integrated, the results can already be seen in the ERP Application. this activity must also be applicable to other modules. 
4.5 Monitoring Data Integration Manager Based on the results of several modules that use Integration Manager namely modules: master data, transaction, report consolidation, the Key User / User task becomes more focused in checking the data in the ERP application system of PT. Argo Pantes, Tbk. One of the advantages in implementing the Integration Manager system is that it checks the data that has been uploaded into the ERP application system, namely the ERP application system still needs to aprroval / post documents that have been uploaded, so that if data errors occur after uploading then the data can still be revised before being posted.

\subsection{Impact of Integration Manager Implementation}

The routine work activities of each department at PT. Argo Pantes, Tbk has become an activity that almost every day dealing with the system, related to the implementation of the Integration Manager is a new learning for users of ERP applications that not all data must always be typed that can cause input errors, in the implementation of integration managers experience a lot of learning for key users / related users [11]. In the measurement, it can be seen a change in the TOWS matrix that is able to describe the changes in learning

Table 3. TOWS matrix integration manager

\begin{tabular}{|c|c|c|}
\hline & Internal Strentgh : & Internal Weakness : \\
\hline External & $\underline{\mathrm{SO}}$ & $\underline{\mathrm{WO}}$ \\
\hline \multirow{6}{*}{$\begin{array}{l}\text { Opportunities } \\
\dot{\dot{ }}\end{array}$} & 1. Able to increase the number & \multirow{6}{*}{$\begin{array}{l}\text { 1. Prepared for the implementation } \\
\text { of integration manager in the } \\
\text { production system } \\
\text { 2. Prepared to eliminate the old } \\
\text { system and reduce input } \\
\text { 3. New findings for the dashboard } \\
\text { integration system }\end{array}$} \\
\hline & of orders. & \\
\hline & and inventories & \\
\hline & 3. The efficiency and & \\
\hline & $\begin{array}{l}\text { effectiveness become more } \\
\text { visible. }\end{array}$ & \\
\hline & $\begin{array}{l}\text { 4. Reduced document } \\
\text { cancellation due to data input } \\
\text { errors }\end{array}$ & \\
\hline External & $\underline{\mathrm{ST}}$ & $\underline{\mathrm{WT}}$ \\
\hline \multirow[t]{5}{*}{ Threats: } & 1. Perform management staff & 1. Conduct Business \\
\hline & $\begin{array}{l}\text { and knowledge Ior a reliable } \\
\text { IT workforce }\end{array}$ & 2. Move the way the user works \\
\hline & 2. Update key users' knowledge & with the IM System \\
\hline & $\begin{array}{l}\text { which is the main role in the } \\
\text { system operation }\end{array}$ & $\begin{array}{l}\text { 3. Changing the mindset of users } \\
\text { and management }\end{array}$ \\
\hline & $\begin{array}{l}\text { 3. Hardware updates in the use } \\
\text { of key users and servers }\end{array}$ & 4. Conduct management trainees \\
\hline
\end{tabular}




\section{DISCUSSION}

The implementation of Integration Manager that runs has a good impact on an organization that implements ERP applications. Especially seen by using the TOWS matrix, the advantages that can be achieved by PT. Argo Pantes, Tbk is in terms of operational activities in inputting data. Learning development also occurs so that with increased understanding of key users / users are expected to improve the performance of an organization

\section{CONCLUSION}

Implementation of Integration Manager is generally carried out in an ERP application that is already running well in an organization, by adding several targets and objectives as well as mapping business processes equipped with key user / user related training in the menu using Integration Manager. The implementation can be said to work well despite several obstacles.

The research continues by measuring the performance of ERP applications that have implemented integration managers, measurements can be done with several methods that support as an appropriate measurement tool.

\section{ACKNOWLEDGEMENT}

The authors would like to express our gratitude for the support provided by Faculty of Science and technology. The financial assistance fromResearch, Publication and Community Service Department Buddhi Dharma University is also greatly acknowledged.

\section{REFERENCES}

[1] Wijaya Santo (2016), "Enhancing Performance of an ERP Systems with a Dashboard Systems". ICIMTECH page 5.

[2] Sutabri, Tata (2012), “Konsep Sistem Informasi”, Yogyakarta : ANDI.

[3] Wayan M. Wijaya (2019), "Teknologi Big Data : Sistem Canggih di balik Google, Yahoo!, Facebook, IBM". Bali : Nilacakra.

[4] Al Mosawi A, Zhao L, \& Macaulay L.A. (2006). A Model Driven Architecture for Enterprise Application Integration. In HICSS (Vol. 39, pp. 4-7).

[5] He W \& Da Xu L (2014). Integration of distributed enterprise applications: A survey. IEEE Transactions on Industrial Informatics, 10(1), 35-42.

[6] Lin CC, Tsai WC \& Shih DH (2008). A Study of Information Systems Reengineering as ERP Is Introduced to Businesses Adapting to the E-Business Era. ICIC, 2008. International Conference

[7] Freddy Rangkuti (2015), "Personal SWOT Analysis : Peluang di Balik Setiap Kesulitan", Jakarta : Gramedia.

[8] Madni AM \& Sievers M (2014). Systems integration: Key perspectives, experiences, and challenges. Systems, 17(1), 37-51.

[9] Reksoatmojo, Wahyuni (2018), “Analisis Dan Perancangan Sistem Basis Data”, Yogyakarta : ANDI.

[10] Sherry Finney \& Martin Corbett (2007) "ERP implementation: a compilation and analysis of critical success factors", Business Process Management Journal, Vol. 13 Iss: 3, pp.329 347

[11] Wijaya Santo (2012).” Esensi dan penerapan ERP dalam bisnis”.Yogyakarta : Graha Ilmu. 


\section{BIOGRAPHY}

Verri Kuswanto,Graduated in Studies Program Information Technology Computer STMIK (S1) Buddhi and also Information Management Systems Focus on Strategic Planning (S2) Bina Nusantara, now currently a Lecturer in Information Systems Study Program, Buddhi Dharma University.

Rudy Arijanto, Graduated in Studies Program Information Management and Computer STMIK (S1) Bina Nusantara and also Informatics (S2) STTI Benarif, now serving as Dean of the Faculty of Science and Technology at the University of Buddhi Dharma.

Andi Leo, obtained his Bachelor of Computer degree at Bina Nusantara University in 1989. And earned his Masters of Computer at Bunda Mulia University in 2004. Now currently a Lecturer in Information Systems Study Program, Buddhi Dharma University. 